\title{
ALGUNOS PROBLEMAS RELATIVOS A LA DISOLUCIÓN Y LIQUIDACIÓN DE LA SOCIEDAD CONYUGAL. UNA ESPECIAL REFERENCIA AL PACTO DE SUSTITUCIÓN DE RÉGIMEN
}

\section{Cristián AEdo Barrena*}

RESUMEN: El presente artículo repasa algunos de los problemas que a propósito de la disolución y liquidación de la sociedad conyugal se han planteado en la doctrina y la jurisprudencia, limitando nuestro análisis a tres aspectos: naturaleza de la comunidad quedada a la disolución de la sociedad conyugal; el alcance del efecto retroactivo de la adjudicación en la disolución de la sociedad conyugal; y algunas cuestiones relativas al acto de sustitución de régimen del artículo 1723 del Código Civil.

PALABRAS CLAVE: Sociedad conyugal - disolución de la sociedad conyugal - comunidad - adjudicación - pacto de sustitución de régimen.

\section{SOME PROBLEMS RAISED BY THE DISSOLUTION AND LIQUIDATION OF THE MARITAL SOCIETY. A SPECIAL REFERENCE TO THE REgime SubSTITUTION PACT}

ABSTRACT: This article goes through some of the problems regarding the dissolution and liquidation of the marital society that have been brought up in the doctrine and jurisprudence, limiting our analysis to three aspects: nature of the remaining community to the dissolution of the marital society; reach of the retroactive effect of the adjudication in the dissolution of the marital society, and some issues relative to the act of regime substitution of article 1723 of the Civil Code.

KEY WORDS: Marital society - marital society dissolution community - adjudication - regime substitution pact.

\footnotetext{
Abogado. Doctor en Derecho por la Universidad de Deusto (España). Profesor de Derecho Civil de la Escuela de Derecho de la Universidad Católica del Norte, sede Antofagasta. Correo electrónico: caedo@ucn.cl

Fecha de recepción: 15 de marzo de 2011.

Fecha de aceptación: 14 de julio de 2011.
} 


\section{INTRODUCCIÓN}

No será necesario justificar la afirmación de que el Derecho de familia ha tenido, como otras materias del Derecho civil, particularmente la responsabilidad civil, un desarrollo considerable. En buena medida, los profundos cambios sociales, traducidos en el acceso de la mujer al mercado laboral y la consagración de la igualdad de géneros, han posibilitado dichos cambios, traducidos en sendas reformas legales. Las expresiones jurídicas de la noción de igualdad, a través de la historia del Derecho, han llegado a estandarizarse y universalizarse. Es así como existen en todas las consagraciones del principio de igualdad el llamado principio o garantía de igualdad ante la ley, la prohibición de hacer distinciones fundadas en el sexo, la raza, el color, la lengua, la religión, las opiniones políticas o cualesquiera otras opiniones, la condición social o económica; la prohibición de crear y gozar de privilegios y fueros; el principio de igualdad en las cargas públicas; la norma de igualdad entre marido y mujer ${ }^{1}$; la regla de igualdad entre hijos legítimos e ilegítimos ${ }^{2}$; e incluso la propugnada igualdad de las parejas, heterosexuales u homosexuales que conviven, frente a las parejas casadas, lo que ha dado lugar a la discusión sobre la necesidad de regular las uniones de hecho. La realidad demuestra, así, que la estructura tradicional de la familia se ha ido modificando, que existen otras realidades que reclaman protección, entre ellas, las parejas de hecho, que terminarán siendo, finalmente, reguladas ${ }^{3}$.

1 Como se sabe, las relaciones jurídicas que emanan del matrimonio quedan entregadas al Derecho privado, principalmente. En nuestro sistema, no existe regulación de estas cuestiones en la Constitución, pero en el Código Civil se ha abierto paso progresivo a la igualdad entre el marido y la mujer. Así, tratándose de regímenes matrimoniales, los derechos de la mujer casada en sociedad conyugal fueron progresivamente mejorados: en virtud de la Ley 10.271, de 2 de abril de 1952, se creó el patrimonio reservado del artículo 150, con la Ley 18.802, de 9 de junio de 1989, se otorgó plena capacidad a la mujer casada en este régimen y se introdujeron importantes reformas en la administración de la sociedad conyugal. Finalmente, con la Ley 19.335, de 26 de octubre de 1998, se creó el régimen patrimonial de participación en los gananciales, bajo su modalidad crediticia, que intenta recoger la problemática social de mujeres -en particular profesionales- que renuncian a un desarrollo personal, al menos durante algún tiempo, por el cuidado de los hijos.

2 Nuevamente, se trata de un ámbito entregado a la regulación del Derecho Civil. La Ley 19.585 , de 26 de octubre de 1998, vino a resolver un viejo problema de discriminación en nuestro país, equiparando a los hijos e igualándolos en derechos. Tan profundo fue este cambio, que una vieja institución proveniente del Derecho romano, como es la patria potestad, siempre aplicable a los hijos nacidos dentro del matrimonio, pasó ahora a regir las relaciones patrimoniales entre padres e hijos, matrimoniales o no y estableciendo la posibilidad de ejercicio por la mujer - no solo a falta del padre- o por ambos padres.

3 Véase (2009) "Regulación jurídica de las parejas de hecho: sobre por qué no equipararlas al matrimonio. Una reflexión desde el caso español". Carlos Pizarro Wilson (coordinador), Estudios de Derecho Civil IV, Jornadas Nacionales de Derecho Civil Olmué, 2008, Santiago de Chile: LegalPublishing. También véase Turner SAelzer, Susan (2008), "Uniones de hecho y regulación legal". A.A.V.V. Estudios de Derecho Civil III. Jornadas Nacionales de Derecho 
También se ha venido sosteniendo que las normas de administración del régimen de sociedad conyugal necesitan una urgente reforma y actualización. Disposiciones como el artículo 1750, solo se comprenden en el contexto en que el marido podía, durante la vigencia del régimen, disponer libremente de los bienes ingresados a la sociedad conyugal ${ }^{4}$.

Pero este desarrollo, propugnado en el ámbito sociológico del Derecho de familia, no se ha traducido en una reflexión renovada de los problemas y dificultades que se presentan en algunos ámbitos patrimo-

Civil, Santiago de Chile: LexisNexis; Gazmuri Riveros, Consuelo (1996), "Uniones de hecho: algunos antecedentes, y problemáticas de la regulación jurídica de sus efectos". A.A.V.V. Instituciones Modernas de Derecho Civil. Homenaje al profesor Fernando Fueyo Laneri, Santiago de Chile: ConoSur, 1996; y Viera Álvvarez, Christian (2008), "El concepto de familia y la unión civil de personas del mismo sexo. Comentario de jurisprudencia a la aplicación de la ley de violencia intrafamiliar". Nomos. Revista de la Facultad de Derecho, Universidad Viña del Mar. No 1.

4 Como señalaba Barros Errázuriz, Alfredo (1931), Curso de Derecho Civil, Santiago de Chile: Editorial Nascimento, vol. IV, p. 158: "Disuelta la sociedad conyugal se produce ipso facto una comunidad de bienes sociales entre el cónyuge sobreviviente y la mujer de marido y, el marido, que durante el matrimonio podia disponer libremente de los bienes sociales, como si fueran de su propiedad, pasa a ser comunero con los herederos de la mujer muerta, en el dominio de dichos bienes". En un interesante trabajo, el profesor Fueyo Laneri abogaba por la reforma del régimen patrimonial, atendiendo, por ejemplo, al principio de la igualdad entre el hombre y la mujer. Sobre el particular, véase Fueyo Laneri, Fernando (1985), "Problemática general del régimen patrimonial del matrimonio". Revista de Derecho y Jurisprudencia, t. 82 , pp. 1 y ss. Y tampoco está de más indicar que estas mismas críticas, es decir, el carácter anacrónico de las normas de la sociedad conyugal, fue el motivo determinante que impulsó la reforma de la Ley 18.802. Véase, sobre este tema, el trabajo de Rozas VIAL, Fernando (1989), "Consideraciones sobre las modificaciones que la Ley $N^{\circ} 18.802$ introduce al Código Civil". Revista Chilena de Derecho, vol. 16, 1. Y debe tomarse nota de los esfuerzos por alterar el carácter del régimen, mediante proyectos de ley. En este sentido, puede citarse el proyecto que pretende la igualdad de marido y mujer en la administración de la sociedad conyugal, ingresado el 4 de octubre de 1995, boletín $\mathrm{N}^{\circ} 1707-18$. El proyecto, que ha tenido una larga tramitación (hasta el año 2008 figura en segundo trámite constitucional en el Senado), pretende la derogación de los artículos 138 y 138 bis, pues reemplaza la denominada sociedad conyugal, por la institución denominada comunidad de gananciales. Algunas normas interesantes del proyecto, son las siguientes: el artículo 165 admite la sustitución del régimen de separación convencional de bienes por el de, ahora, de comunidad de bienes, en plena concordancia con la reforma que se introduce, también, en el artículo 1723. El artículo 1725 declara ahora que disuelta la comunidad de gananciales se forma una comunidad entre los cónyuges: se fija su activo y se determina el pasivo del que deberá responder (artículos 1725 y 1740, en relación con el artículo 1741). El artículo 1742 del proyecto introduce una norma que consagra, a nuestro juicio, una norma de protección general a favor de los terceros, pues dispone que los acreedores (suponemos, anteriores a la liquidación), pueden hacer efectivos sus créditos en cualquiera de los bienes adjudicados a los cónyuges. Finalmente, el artículo 1749 ahora es reemplazado, en la medida que permite a cada cónyuge administrar libremente sus bienes, con las limitaciones que para el marido contempla hoy la misma disposición, derogándose los artículos 1751 a 1763. Véanse los interesantes comentarios que formula al proyecto Corral Talciani, Hernán (2007), "Reforma al régimen de bienes del matrimonio. Reflexiones críticas sobre el Proyecto de Ley que sustituye la sociedad conyugal como régimen legal supletorio". Documento de trabajo. Universidad de los Andes, 66, publicado en http://corraltalciani.files.wordpress.com/2010/04/reformaregbienes.pdf (fecha de la visita: 20 de febrero de 2011). 
niales del Derecho de familia. Particularmente, consideramos que algunos extremos relativos al régimen de sociedad conyugal, no han recibido la atención requerida por la doctrina, no obstante que los conflictos siguen presentándose. Por eso, el objeto de este artículo es analizar algunos de los problemas que se presentan a propósito de la disolución y liquidación de la sociedad conyugal, aspectos que revisaremos en los apartados siguientes. Concretamente, los problemas que abordaremos dicen relación con la naturaleza de la comunidad quedada a la disolución de la sociedad conyugal; el alcance del efecto retroactivo de la adjudicación en la disolución de la sociedad conyugal; y algunas cuestiones relativas al acto de sustitución de régimen del artículo 1723.

\section{1) UN MARCO TEÓRICO APROPIADO: LA NATURALEZA JURÍDICA DE LA SOCIEDAD CONYUGAL}

Tanto la doctrina como la jurisprudencia están de acuerdo en que la sociedad conyugal no tiene la naturaleza jurídica de una comunidad, técnicamente hablando. En principio, existen una serie de patrimonios de afectación: un haber absoluto, otro relativo, patrimonios propios de cada cónyuge y los patrimonios especiales de los artículos 150, 166 y 167 del Código Civil. A todo ello se suma un entramado de normas que regulan el régimen de administración: el marido administra tanto los bienes sociales como los bienes propios de la mujer (artículos 1749 y 1754 del Código Civil), sujeto a las limitaciones que las mismas normas antes citadas establecen, y a las reglas especiales de los artículos 138 y 138bis, sin perjuicio de la administración extraordinaria de la sociedad conyugal (artículos 1758 y siguientes). Y, como si el cuadro no fuese complejo, el régimen de administración limitada, puede superponerse al sistema de coadministración de los bienes familiares, como lo prescriben los artículos $140, \mathrm{~N}^{\circ} 1$, en relación con los artículos 141 y siguientes 5 .

5 En general, desde temprano, nuestra doctrina llegó a la conclusión, con argumentos similares, de que se trataba de una institución sui generis. Esta es la opinión, por ejemplo, de Barros (1931) 110. Fueyo Laneri, Fernando (1959), Derecho Civil, t. VI: Derecho de Familia, Santiago de Chile: Imprenta Universo, pp. 25-27. Frigerio Castaldi, César (1995), Regímenes matrimoniales, Santiago de Chile: Editorial Jurídica ConoSur, p. 23. Rodríguez Grez, Pablo (1996), Regimenes Patrimoniales, Santiago de Chile: Editorial Jurídica de Chile, pp. 39 y ss. Ramos Pazos, René (2005), Derecho de Familia, Santiago de Chile: Editorial Jurídica de Chile, $5^{a}$ edición actualizada, t. I, pp.143-144, sostiene que no estamos en presencia de una comunidad, pues la mujer no tiene derecho alguno sobre los bienes sociales, vigente el régimen y el marido es el dueño, respecto de terceros (arts. 1750 y 1752 del CC). Por la misma razón, descarta que estemos frente a una persona jurídica, por lo que entiende que se trata de una figura sui generis, con características propias, asemejándose, en todo caso, a un patrimonio de afectación. Una opinión similar sostienen, entre otros, López Díaz, Carlos (2005), Manual de Derecho de Familia y Tribunales de Familia, Santiago de Chile: 
Pero no cabe duda alguna de que no estamos frente a una persona jurídica, no obstante la diversidad de patrimonios: para los terceros, el marido es el dueño de los bienes sociales y las deudas contraídas por este (sujeto a las limitaciones del régimen) obligan tanto sus bienes personales, como sus bienes propios, como expresamente disponen los artículos 137 y 1750 del Código Civil.

Sin embargo, habrá que convenir las dificultades que pudieran presentarse con el sistema registral chileno. Piénsese, por ejemplo, en la adquisición de un bien inmueble a título oneroso por la mujer, durante la vigencia del régimen, sin que se configuren los requisitos del artículo 150 del Código Civil ${ }^{6}$. O la hipótesis, bastante común, en la que los cónyuges, casados en sociedad conyugal, adquieren una propiedad en calidad de comuneros.

En el primer caso propuesto, figurará el inmueble inscrito a nombre de la mujer, pero las normas de administración del régimen nos advierten que el poseedor inscrito no tiene parte alguna, frente a los terceros, sobre dicho bien, porque se trata de un inmueble social. No es solo que al marido le competa la administración y que, en consecuencia, sea él el que deba comparecer en el acto en el que se pretende enajenar dicho inmueble, sino que el artículo 1750 establece que es el marido, respecto de terceros, el dueño de los bienes raíces sociales. ¿Cuál es el sentido que debe otorgársele a la expresión? Por ejemplo, si un tercero pretendiera derechos sobre dicho bien raíz social o si, peor aún, se configura un problema de inscripciones paralelas, ¿a quién corresponde el ejercicio de la acción reivindicatoria? Si se enajena y resulta evicta, ¿a quién debe citar el comprador?

Librotecnia, 2a edición, t. I, pp. 322-323, y Troncoso Larronde, Hernán (2006), Derecho de Familia, Santiago de Chile: LexisNexis, 8a edición, p. 142. Por su parte, Court MuRAsso, Eduardo (2009), Curso de Derecho de Familia, Santiago de Chile: LegalPublishing, pp. 131-132, indica también que se trata de una institución sui generis, pero agregando la importante cuestión de que tampoco se le puede considerar un patrimonio de afectación, desde que el marido es dueño, respecto de los terceros, de los bienes sociales. Ciertamente, la discusión tiene larga data, pues puede remontarse a los primeros comentaristas del Derecho Civil francés. Véase Belluscio, Augusto César (2004), Manual de Derecho de Familia, Buenos Aires: Astrea, $1^{\text {a }}$ reimpresión de la $7^{\text {a }}$ edición, t. II, pp. 57-59. Para el problema en el antiguo derecho francés, véase Laurent, F. (1878), Principes de Droit Civil, Bruselas: Bruylant, $3^{\mathrm{a}}$ edición, t. 21, pp. 223 y ss.

6 Debe descartarse la hipótesis de que un bien adquirido a título oneroso por la mujer, durante la vigencia del régimen, pueda configurar de pleno derecho o automáticamente el ingreso de dicho bien al patrimonio reservado. En principio, se requiere que la mujer ejerza un empleo u oficio separado del marido, pero, además, debe tenerse muy en cuenta el inciso $4^{\circ}$ del artículo 150: "Los terceros que contraten con la mujer quedarán a cubierto de toda reclamación que pudiere interponer ella o su marido, sus herederos o cesionarios, fundada en la circunstancia de haber obrado la mujer fuera de los términos del presente artículo, siempre que, no tratándose de bienes comprendidos en los artículos 1754 y 1755, se haya acreditado por la mujer, mediante instrumentos públicos o privados, a los que se hará referencia en el instrumento que se otorgue al efecto, que ejerce o ha ejercido un empleo, oficio, profesión o industria separados de los de su marido". 
El segundo caso todavía es más complejo, porque si un bien es adquirido en comunidad, a título oneroso, durante la vigencia de la sociedad conyugal, el bien pertenecerá a la sociedad conyugal, pero además habrá que tener en cuenta el régimen de administración propio de la comunidad. Surgen, entonces, problemas interesantes, ¿podrían los cónyuges pactar un régimen de administración especial, solo respecto de la cosa común? Disuelta la sociedad conyugal y antes de la liquidación, partiendo del supuesto de que estamos en presencia de una comunidad, la Corte Suprema ha admitido que la mujer puede deducir una tercería de dominio si se ha embargado un bien raíz de la comunidad ${ }^{7}$. En cambio, si vigente la sociedad conyugal, se embarga un bien que pertenece al haber absoluto de la sociedad, pero que, como en la hipótesis propuesta, ha sido adquirido en comunidad, ¿puede la mujer deducir una tercería de dominio, aun cuando el artículo 1750 considere al marido dueño exclusivo de los bienes sociales?

\section{2) NATURALEZA JURÍDICA DE LA COMUNIDAD QUE QUEDA A LA DISO- LUCIÓN DE LA SOCIEDAD CONYUGAL}

Como se sabe, disuelta la sociedad conyugal, con arreglo al artículo 1764 del Código Civil, se forma una comunidad entre los cónyuges que debe ser liquidada, siguiendo para ello las reglas de la partición. La doctrina está de acuerdo en que, a la disolución de la sociedad conyugal, se forma una comunidad entre los cónyuges. Desde luego, en los casos de las causales contenidas en los números $1764 \mathrm{~N}^{\circ} 1$, en relación con el artículo 42 de la Ley $\mathrm{N}^{\circ}$ 19.947, en adelante LMC, en los supuestos divorcio; y en los casos de los números 3 y 4, es decir, las sentencias de separación judicial, separación total de bienes y la que declara la nulidad de matrimonio; finalmente, por el pacto de sustitución de régimen, del artículo 1723 del Código Civil. La comunidad, no obstante, también puede formarse entre el cónyuge sobreviviente y los herederos del fallecido, en los supuestos de los números 1 y 2 del artículo 1764, es decir, muerte natural (en relación con el artículo 42 de la LMC), y la muerte presunta (en relación con el artículo 84 del Código Civil).

No dispone explícitamente la ley la conformación de dicha comunidad, pero no se puede desprender otra cosa de los artículos 1774 y 1776. Conforme a la primera disposición: "Ejecutadas las antedichas deducciones, el residuo se dividirá por mitad entre los dos cónyuges". Y, respecto de la segunda: "La división de los bienes sociales se sujetará a las reglas dadas para la

Véase el fallo de la Corte Suprema, de 26 de enero de 2005, rol №4717-2003, indicador LegalPublishing $\mathrm{N}^{\circ} 31771$ (fecha de la visita, 20 de febrero de 2011). 
partición de los bienes hereditarios". No haría falta la disposición, porque el artículo 2313 sujeta a las comunidades a las reglas de la partición, pero, precisamente en virtud de dicha regla especial, puede afirmarse que la naturaleza es la de una comunidad ${ }^{8}$.

Desde luego, la jurisprudencia ha enfatizado también el carácter de comunidad. Por ejemplo, en la sentencia de la Corte Suprema, de 23 de marzo de 2009, rol No 6890-2007, la Corte consideró que siempre la disolución de la sociedad conyugal da lugar a la formación de una comunidad o sociedad de hecho, que debe dividirse ${ }^{9}$.

Con todo, el problema estriba en resolver la naturaleza de dicha comunidad, ¿estamos en presencia de una indivisión que supone una universalidad jurídica, como en la herencia o solo se trata de una comunidad que recae sobre bienes individualmente considerados? La cuestión no es menor, si pensamos en las consecuencias jurídicas que supone adoptar una posición u otra.

Como afirma Somarriva, de las distintas categorías de indivisión, la que distingue entre indivisión sobre una cosa universal e indivisión sobre una cosa singular, que es la que nos interesa, está expresamente reconocida en nuestra legislación, por cuanto, el artículo 1317 dispone: "Ninguno de los coasignatarios de una cosa singular o universal será obligado a permanecer en la indivisión". Para Somarriva, estamos en presencia de una indivisión que recae sobre una cosa universal, cada vez que la comunidad recaiga sobre un patrimonio, es decir, un conjunto de bienes y pasivos, distinto del patrimonio, que antes de los indivisarios, ha tenido otro titular. En cambio, si la comunidad tiene por objeto bienes determinados, no estamos en presencia de una indivisión sobre cosa universal ${ }^{10}$.

8 En cuanto a la doctrina, véase, desde temprano, Lira Urquieta, Pedro (1936), "Algunas consideraciones sobre el estado de indivisión que sigue a la disolución de la sociedad conyugal". Revista de Derecho y Jurisprudencia, t. 33, pp. 113-114. También Somarriva UNDurraga, Manuel (1963), Derecho de Familia, Santiago de Chile: Editorial Nascimento, p. 310. Modernamente, Ramos (2005) 248. Troncoso (2006) 208-209, con la importante puntualización que, con toda razón, el autor indica que en el caso que la mujer renuncie a los gananciales, no se genera una comunidad; CourT (2009) 182. También es una opinión común en el Derecho comparado, que admite el régimen de la sociedad conyugal. En el ordenamiento argentino, por ejemplo, Belluscio (2004) 181.

$9 \quad \mathrm{~N}^{\circ}$ LegalPublishing: 41822 (fecha de visita 20 de enero de 2011). Véase también el fallo de la Corte Suprema, de 10 de septiembre de 2008, $\mathrm{N}^{\circ}$ de LegalPublishing 39787 (fecha de visita, 20 de enero de 2011).

10 Somarriva Undurraga, Manuel (2006), Indivisión y partición, Santiago de Chile: Editorial Jurídica de Chile, reimpresión de la $5^{a}$ edición, actualizada por Gonzalo Figueroa Yáńez, pp. 39; 42. Véase también, Silva Segura, Enrique (1985), Acciones, actos y contratos sobre cuotas, Santiago de Chile: Editorial Jurídica de Chile, pp. 54-55, una universalidad jurídica se caracteriza porque está compuesta de bienes y deudas, con un activo y un pasivo correlativo de una masa de bienes. La comunidad de hecho, en cambio, está conformada por un conjunto de activos, pero carece completamente de pasivos. Aún así, este autor no comparte la opinión de Somarriva, en orden al reconocimiento legal de las universalidades jurídicas. Considera, por el contrario, que el artículo 2304, al referirse a las comunidades sobre cosa 
Las consecuencias entre ambos tipos de indivisión, son considerables. Según el profesor Somarriva, en la comunidad sobre universalidad, se producen las siguientes: en principio, el derecho del comunero es indeterminado, como lo denomina "flotante", que solo va a determinarse hecha la partición ${ }^{11}$. Ello es precisamente lo que justifica, en su concepto, el efecto declarativo de la partición, conforme al artículo 1344 . Y, como el derecho tiene carácter indeterminado, es decir, no se comunica con los bienes que componen la indivisión, la tradición no se sujeta a las reglas de los bienes raíces, ni puede rescindirse la compraventa, por ejemplo, por lesión enorme ${ }^{12}$. En la indivisión sobre cosa singular, los efectos son los inversos ${ }^{13}$.

universal, están pensando en universalidades de hecho, no de Derecho, porque la regulación del cuasicontrato de comunidad fue tomada de Pothier y este autor solo se refería a las comunidades de hecho. Agrega que en la universalidad jurídica no puede hablarse de indivisión, puesto que el pasivo no permanece intacto al transmitirse a varios titulares; por el contrario, este se distribuye entre los varios herederos. De este modo, piensa, solo entre las cosas que no se dividen ipso iure puede hablarse de comunidad, por lo que en la sucesión, estaríamos en presencia de una comunidad de hecho y no de Derecho.

11 Como señalan Alessandri R., Arturo, Somarriva U., Manuel y Vodanovic H., Antonio (2001), Tratado de los Derechos reales, Santiago de Chile: Editorial Jurídica de Chile, 6a edición, t. I, pp. 112-113, cada copropietario es considerado dueño individual y exclusivo de su cuota-parte, pero la suerte de los actos sobre esa cuota-parte quedan subordinados a las resultas de la partición. Para Vodanovich H., Antonio (2001), Manual de Derecho Civil. Parte preliminar y general, Santiago de Chile: ConoSur, pp. 356-357, en la universalidad de derecho, se forma un conjunto orgánico, creado por ley, de relaciones jurídicas activas y pasivas pertenecientes a un mismo sujeto y que se miran como un todo unitario en consideración a un fin determinado.

12 Somarriva (2006) 40-41. La comunicabilidad de la cuota con los bienes que componen la comunidad es una cuestión sumamente compleja y debatida en la doctrina. Como explica Peñailillo Arévalo, Daniel (2002), Los bienes. La propiedad y otros derechos reales, Santiago de Chile: Editorial Jurídica de Chile, $3^{\text {a }}$ edición, pp. 102-103, la doctrina dominante, admitiendo que el Código se inspira en la concepción romana, entiende que no se ha seguido en este punto, recayendo el derecho de cada comunero en la cosa común y no en los bienes que la componen, lo que explicaría el efecto declarativo de la partición; sin embargo, agrega que se ha puesto en duda esta concepción, por cuanto hay buenos argumentos para entender que en el Código se consagra la comunicación entre la cuota y los bienes individuales. En la tesis de Silva (1985), 89-90, hay que distinguir: de un lado, el derecho real de herencia supone, efectivamente, una relación entre el heredero y el patrimonio del causante; pero: "...al mismo tiempo que el heredero adquiere el derecho real de herencia se hace dueño de todos aquellos bienes que eran de propiedad del causante, sean corporales e incorporales, y cuando hay varios herederos, éstos pasan a ser condueños de las cosas que pertenecian al causante. Se forma una comunidad de dominio sobre una cosa universal, el conjunto de bienes del causante, según el artículo 2304". Por lo mismo, la cuota queda siempre comunicada con los bienes sobre los que recae la indivisión; otra cuestión es la cesión del derecho real de herencia.

13 Aun así, debe advertirse que, siguiendo a Somarriva (2006) 465, en la comunidad singular, si bien es cierto debería llegarse a la conclusión de la inaplicabilidad del efecto declarativo, las disposiciones legales, especialmente el artículo 1317, que reconoce ambos tipos de indivisión, no permite dudar sobre el alcance de la norma, es decir, que el título (incluyendo el efecto declarativo), se aplicaría tanto a las comunidades universales, como singulares, claro que, en este caso, estaríamos frente, según Somarriva, a una verdadera ficción. Véase también, Somarriva Undurraga, Manuel (2005), Derecho Sucesorio Santiago de Chile: Editorial Jurídica de Chile, 7a edición actualizada, versión de René Abeliuk, t. II, p. 639. 
Para Somarriva, no cabe duda que la comunidad que resulta de la disolución de la sociedad conyugal, sea entre los cónyuges o bien entre el cónyuge sobreviviente y los herederos del fallecido, tiene la naturaleza, como el derecho real de herencia, de una universalidad jurídica ${ }^{14}$. Esta es también la opinión categórica de Ramos Pazos, quien subraya la circunstancia que disuelta la sociedad conyugal, se genera una comunidad a título universal, pues recae sobre un patrimonio, con un activo y un pasivo, incluyendo el activo todos los bienes que eran de la sociedad, inclusive los reservados y, en el pasivo, todas la deudas sociales, incluidas las adquiridas en el patrimonio reservado ${ }^{15}$.

Pueden hallarse algunas sentencias que siguen este criterio, es decir, que estamos en presencia de una comunidad a título universal. Por ejemplo, en el fallo de la Corte de Apelaciones de Concepción, de 15 de enero de 2008, se declaró: "Toda vez que el divorcio legalmente declarado pone término a la sociedad conyugal, generándose una comunidad a título universal entre los ex cónyuges sobre todo el patrimonio, correspondiendo a cada uno un derecho de dominio cuotativo sobre el bien..." 6 .

Como indica Ramos Pazos, los tribunales han acogido este criterio cuando han permitido las tercerías de dominio, en los casos de embargo de un bien perteneciente a la comunidad. Los tribunales han entendido que, en tal caso, el cónyuge puede alegar la exclusión de los derechos recaídos sobre el bien embargado. Por ejemplo, en la sentencia de la Corte de Apelaciones de Santiago, de 7 de enero de 1998, la Corte declaró que: "Los acreedores de uno de los cónyuges, por deudas posteriores a la disolución de la sociedad conyugal, podrán perseguir y embargar bienes propios y los derechos que, como comunero, le corresponden sobre los bienes sociales, pero de ninguna manera la totalidad de éstos y si de hecho la embargaren, el otro cónyuge o sus herederos pueden deducir la correspondiente tercería para que el embargo se reduzca a esos derechos. Una vez disuelta la sociedad conyugal nace una comunidad sobre los bienes sociales cuyos propietarios son ambos cónyuges"17. En el fallo de la Corte Suprema, de 26 de enero de 2005, el tribunal reiteró el criterio de que disuelta la sociedad conyugal, se genera una comunidad, de modo que ambos tienen una cuota en el derecho de dominio de la cosa: "Por lo mismo, a la fecha en la que se trabó el embargo, el marido ejecutado solo era dueño del $50 \%$ del derecho de dominio sobre la $\cos a \ldots " 18$.

SOMARRIVA (2006) 39.

Ramos (2005) 248-249.

Fallo publicado en Microjuris, indicador MJJ16506, causa rol N 1987-07 (fecha de la visita: 26 de enero de 2011).

Fallo publicado en Microjuris, indicador MJJ469 (fecha de la visita: 26 de enero de 2011).

Sentencia publicada en LegalPublishing, $\mathrm{N}^{\circ} 31771$, causa rol $\mathrm{N}^{\circ} 4717-2003$ (fecha de la visita: 5 de enero de 2011). 
Hay algunos autores que se muestran escépticos. Para Peñailillo, la cuestión es discutible, aunque no profundiza en el problema ${ }^{19}$. Una opinión muy interesante sostuvo Lira Urquieta, quien la califica como una comunidad de hecho. Para él, enfocando el asunto desde la perspectiva de los frutos y aumentos de los bienes comunes, la disolución de la sociedad conyugal supone que esta deviene en una comunidad de hecho, agregando que los frutos, aumentos y mejoras deben dividirse entre los cónyuges por mitades y no según el aporte a la comunidad, como resulta de la interpretación armónica de los artículos 1772 y 1774 . Ello quiere decir, según Lira, que el Código ha asumido una posición ecléctica, abandonando el rigorismo que hubiese implicado aceptar la subsistencia de una comunidad a tábula rasa, lo que importa concluir que subsiste, mediante una suerte de ficción legal, el régimen de la sociedad conyugal en algunos $\operatorname{aspectos}^{20}$. Siendo así, a nuestro juicio, es difícil pensar en una universalidad.

A nuestro juicio, una precisión, de la mano de Silva Segura, se impone. Así como en la sucesión por causa de muerte debe distinguirse entre el derecho real de herencia, que sí constituye una universalidad jurídica que recae sobre el patrimonio del causante, y el derecho de dominio recaído sobre los bienes que componen ese patrimonio, diferencia expresamente admitida en el artículo 1268 del Código Civil, es necesario tener en cuenta este criterio a la hora de analizar la comunidad que se forma disuelta la sociedad conyugal ${ }^{21}$. Como señalan Díez-Picazo y Gullón, la universalidad no es un objeto distinto de las cosas que lo componen; no tiene existencia ontológica, sino lógica. En las universalidades de hecho, existe un agregado de bienes de la mano del hombre (un rebańo, una pinacoteca);

Peñailillo (2002) 48-49.

LiRA (1936) 122-123. En el Derecho argentino, es muy discutida su naturaleza jurídica y algunos autores, como explica Belluscio, han negado que a la disolución de la sociedad conyugal estemos frente a una universalidad jurídica, sino que condominio sobre bienes, porque no existe la correlación con un pasivo. Véase, Belluscio (2004) 182. De acuerdo con Bossert, Gustavo y Zannoni, Eduardo (2004), Manual de Derecho de Familia, Buenos Aires: Astrea, 6a edición actualizada, p. 301, es preferible referirse a la liquidación de gananciales, desde que entienden que hay masas de bienes independientes del marido y de la mujer.

21 Silva (1985) 11. Esta perspectiva también ha sido sustentada por STitchkin B., David (1949), "Comentario a la sentencia de la Corte Suprema, de 18 de marzo de 1948". Revista de Derecho y Jurisprudencia, t. 46, 2a parte, sec. 2a $2^{\mathrm{a}}$, pp. 95-98. Explica el profesor Stitchkin que, a diferencia del sistema francés, en el que se asimila el derecho de herencia al dominio, el artículo 1268 consagra la autonomía e independencia de la herencia respecto del dominio y "... deja de manifiesto que el adquirente de la herencia incorpora a su patrimonio dos derechos: el de dominio sobre las cosas singulares de que el causante era dueño y el de herencia sobre la universalidad jurídica constituida por el patrimonio del causante o por la parte alícuota del patrimonio en que opera la sucesión, según se trate de uno o varios herederos". De este modo, en su opinión, la adquisición de la herencia no supone, necesariamente, la adquisición del dominio de las cosas que forman parte de la sucesión. 
en cambio, las universalidades jurídicas suponen la agregación de cosas materiales y derechos, pero por obra de la ley ${ }^{22}$.

Partiendo de estos supuestos, a nuestro juicio, hay buenas razones para dudar de la naturaleza o carácter de la comunidad quedada a la disolución de la sociedad conyugal. En principio, porque, a diferencia de la herencia, es evidente que en la comunidad entre los cónyuges, no se ha reconocido la existencia de un derecho real distinto e independiente del dominio, como lo dispone el artículo 1268 del Código Civil.

Pero al margen de esta consideración, no se aprecia en la comunidad que queda a la disolución de la sociedad conyugal un conjunto correlativo de activos y pasivos. En efecto, así como se reputa al marido dueño de los bienes sociales vigente la sociedad conyugal y que la mujer, por sí sola, no tiene derecho en los bienes sociales (artículos 1750 y 1752), disuelta la sociedad conyugal, de acuerdo con lo que dispone el artículo 1778, el marido es el responsable del total de las deudas de la sociedad, salvo la acción contra la mujer para el reintegro de la mitad de sus deudas, con la limitación del beneficio de emolumentos. Ello quiere decir que el pasivo se encuentra dividido por ley y no exactamente en proporción a lo que se recibe, ni tampoco subsiste esta división para los terceros, lo que constituye una diferencia elemental con la herencia ${ }^{23}$. No existe una transmisión de un patrimonio, porque el único titular, antes de disolverse la sociedad conyugal es el marido y, después de disuelta, lo es también en relación con las deudas, de modo que solo se podría pensar en un condominio sobre una masa de bienes. La jurisprudencia invocada por los partidarios de la tesis de la universalidad jurídica, de hecho, se refiere claramente a la comunicabilidad de la cuota de cada cónyuge con los bienes que, en particular, integran los gananciales.

\section{3) EFECTOS DE LA ADJUdicaCión EN LA LIQUidaCión DE LA COMUNIDAD}

Pero no solo existe controversia en relación con la naturaleza de la comunidad quedada a la disolución de la sociedad conyugal. También hay problemas para determinar desde cuándo existe dicha comunidad. Los casos más importantes se han presentado especialmente tratándose del pacto de sustitución de régimen del artículo 1723, al que luego aludiremos. La

22 Díez-Picazo, Luis y Gullón, Antonio (2003), Sistema de Derecho Civil, Madrid: Tecnos, $11^{\text {a }}$ edición, vol. I, p. 407.

23 Véase, Ramos (2005) 265-270, quien distingue, como la mayoría de nuestra doctrina, entre obligación a la deuda y contribución a la misma, sin perjuicio que los cónyuges puedan pactar otra forma de distribución, en atención a los artículos 1776, 1340 y 1359. En términos muy similares, entre otros, Rodríguez Grez (1996) 187-188 y Troncoso (2006) 214. 
cuestión puede analizarse del siguiente modo. Ya hemos visto que, disuelta la sociedad conyugal, se forma una comunidad de bienes entre los cónyuges, que se somete a las reglas de partición de bienes, en virtud de los artículos 1774 y 1776 del Código Civil, es decir, a los artículos 1317 y siguientes. Sabemos, además, que el proceso de partición culmina con la adjudicación, que se traduce en la individualización de una cosa que se poseía antes en común. La adjudicación supone un efecto declarativo, es decir, que se retrotraen sus efectos a la época en la que ha operado el modo de adquirir. Así ocurre en la sucesión por causa de muerte. Es por esta razón que la adjudicación, en nuestro sistema y a diferencia del Derecho romano, no opera como modo de adquirir el dominio. ¿Qué ocurre en la comunidad que queda a la disolución de la sociedad conyugal?

Piénsese en la hipótesis siguiente: el marido ha contraído una deuda social, durante la vigencia del régimen, pero una vez disuelta, celebra con su mujer un pacto de sustitución de régimen y es a la mujer a quien se adjudican los bienes. Varias cuestiones pueden plantearse, sin perjuicio de los efectos del pacto de sustitución, que analizaremos más adelante, ¿qué ocurre con las hipotecas constituidas para garantizar dichos créditos?, ¿se encuentran en la misma situación los créditos, con independencia de su fuente? La pregunta no es baladí. Puede ocurrir, por ejemplo, que el marido haya cometido un ilícito civil vigente la sociedad conyugal, pero que la sentencia sea posterior a la disolución del régimen o, incluso, a la liquidación, ¿puede el acreedor perseguir los bienes adjudicados a la mujer?

En la doctrina, hay relativo acuerdo en que la adjudicación retrotrae los efectos a la época de disolución de la sociedad conyugal, fundándose en el criterio unánime de que, vigente el régimen, no existe una verdadera comunidad $^{24}$. Una opinión distinta tiene Rodríguez Grez, quien indica que adjudicados los bienes, el cónyuge adjudicatario se entiende dueño del bien desde la adquisición por la sociedad ${ }^{25}$.

Nuestra jurisprudencia ha tenido oportunidad de pronunciarse sobre estos problemas y ha limitado el efecto declarativo de la partición en la sociedad conyugal. En el fallo de la Corte de Apelaciones de Puerto Montt, de 12 de noviembre de 2010, se advierte que: "Si bien la división de los bienes sociales, se sujeta a las reglas dadas para la partición de los bienes hereditarios, de ello deriva que la adjudicación de los bienes sociales participa de la misma naturaleza, principios y efectos que la partición de bienes hereditarios, sin embargo el efecto retroactivo de la partición de bienes difiere de la comunidad hereditaria, toda vez que durante la vigencia de la sociedad conyugal no hay comunidad entre los cónyuges, marido y mujer no son copropietarios de los bienes sociales no teniendo la mujer por si sola

Véase, entre otros, Somarriva (2006) 469-470.

RodríGuez Grez (1996) 189. 
derecho alguno, tal como lo prescribe el artículo 1752 del Código Civil. De acuerdo a lo expuesto, debe considerarse que el inmueble que se adjudicó la ejecutada en la escritura de separación de bienes y liquidación de la sociedad conyugal, pasó a ser de su dominio exclusivo desde la suscripción de la misma, no pudiendo extenderse este efecto retroactivo a una fecha anterior, al no existir comunidad entre ellos antes de la celebración del pacto de separación de bienes" 26 .

El principio establecido en este interesante fallo limita razonablemente los efectos retroactivos de la adjudicación, pero no se trata de una decisión aislada. En la sentencia de la Corte de Apelaciones de Santiago, de 22 de diciembre de 2008, se vuelven a destacar las diferencias entre el alcance del efecto declarativo de la partición, en la sucesión por causa de muerte y en la liquidación de la sociedad conyugal. Precisamente, como indica Somarriva, uno de los efectos de la partición y del efecto retroactivo consagrado en el artículo 1344 del Código Civil, es la caducidad del embargo constituido por un comunero a quien no se ha adjudicado el bien embargado ${ }^{27}$. En el caso presentado en el fallo que comentamos, la Corte resolvió que el embargo trabado vigente la sociedad conyugal, no queda afectado por la liquidación y la adjudicación al cónyuge que no era el deudor, rechazando la tercería de dominio deducida por el adjudicatario $^{28}$.

Es necesario indicar de todos modos, que la cuestión tiene indudable relación con la inoponibilidad que deriva del pacto de sustitución, en cuanto este no puede afectar, en ningún caso, los derechos de los terceros, adquiridos con anterioridad al pacto, pero de esta materia nos ocuparemos más adelante. Por la misma razón, consideramos que se han confundido dos cuestiones distintas en esta materia. Si bien es cierto la discusión relativa a los alcances o efectos de la adjudicación pierde fuerza frente a la protección de los terceros en el pacto de sustitución, especialmente cuando la jurisprudencia, como veremos, parece entender que opera una suerte de inoponibilidad de pleno derecho, la sociedad conyugal se disuelve por otras causales, que pueden, a su vez, disolver o no el matrimonio y en el que no existe un principio análogo al consagrado en el artículo 1723.

Ahora bien, sin perjuicio que es razonable la limitación al efecto retroactivo establecido por la jurisprudencia, subsiste un problema jurídico que no es menor. Dado que la adjudicación no constituye modo de adquirir el dominio, precisamente porque opera con efecto retroactivo,

\footnotetext{
26 Sentencia publicada en Microjuris, MJJ25584, rol N 170-10 (fecha de la visita: 25 de enero de 2011).

27 Somarriva (2006) 478. También en Somarriva (2005) 643.

28 Fallo publicado en LegalPublishing, $\mathrm{N}^{\circ} 41366$, rol $\mathrm{N}^{\circ} 7539-2007$ (fecha de la visita: 5 de enero de 2011).
} 
habrá que buscar la causa de adquisición en un modo de adquirir. En la sucesión por causa de muerte, siguiendo a Somarriva, la adjudicación se retrotrae al momento en el que nace la indivisión, es decir, cuando opera el modo de adquirir sucesión por causa de muerte ${ }^{29}$. Pero en la sociedad conyugal la cuestión es distinta. A diferencia de la indivisión hereditaria, la comunidad nace, como sabemos, disuelta la sociedad conyugal, pero el modo de adquisición es anterior, necesariamente.

Frente a este escenario tenemos dos alternativas. Una posibilidad sería entender que, al disolverse la sociedad conyugal opera, como modo de adquirir, la ley. La posición, en todo caso, adolece de evidentes reparos y debilidades, porque, para que la ley opere como modo, debe ordenar directamente la adquisición del dominio. ${ }^{30}$ Pero habrá que decir en apoyo de esta opción que, admitido que la sociedad conyugal no es una comunidad, es difícil comprender la adquisición del dominio desde la tradición, cuando el adjudicatario es el cónyuge que no concurrió a dicho acto. Esto ocurrirá muy claramente, a nuestro juicio, en dos hipótesis distintas. Primero, en la adquisición del dominio de un inmueble a título oneroso por el marido. Éste pertenecerá a la sociedad conyugal, de acuerdo con lo prescrito en el artículo 1725. Como la sociedad conyugal no es una persona jurídica y, además, teniendo presente que el marido es respecto de terceros dueño exclusivo de los bienes sociales (artículo 1750) y que la mujer no tiene derecho alguno sobre ellos (artículo 1752), ¿cómo llega la mujer a ser comunera? Porque la adquisición del dominio para el marido puede explicarse por la tradición, pero no es el caso de la mujer. Luego, si la mujer es la adjudicataria del bien, es difícil explicar que el efecto declarativo de la partición opere desde la adquisición del dominio, mediante la tradición.

Pongámonos, ahora, en el caso contrario. La mujer ha adquirido un bien raíz en virtud de su patrimonio reservado, pero, como no ha renunciado a los gananciales, este bien ingresa a la comunidad generada a la disolución del régimen. El artículo 150 dispone expresamente que disuelta la sociedad conyugal, dichos bienes formarán parte de la masa común de bienes. Y, tanto el artículo $166 \mathrm{~N}^{\circ} 3$, como el artículo 167, se remiten al artículo 150 para estos efectos. ¿No podría pensarse en estos casos que la ley establece directamente la comunidad?

La segunda alternativa sería considerar que los tribunales han actuado para restringir los alcances de la norma, que, al margen de la protección contenida en el artículo 1723, podría presentar serios inconvenientes para los terceros. No es la primera vez que los tribunales actúan de esta forma. Como indican los profesores Domínguez, en un interesante tra-

SomArRIVA (2006) 469.

Véase, por todos, Alessandri, Somarriva y Vodanovic (2001) 133. 
bajo, las sentencias pueden, en los hechos, "llevarse" un precepto legal, al determinar su restricción o, derechamente, su inaplicación ${ }^{31}$.

Siguiendo a Vigo, el paradigma dogmático o racionalista, pretende y confía que el juez opere sometido a las exigencias propias de la razón teórica o científica exacta, de modo que con sencillez y certeza absoluta deduzca acríticamente desde la ley la solución al caso, tal cual la quiso el legislador. Este modelo parte asumiendo la capacidad todopoderosa del legislador, como único creador del Derecho ${ }^{32}$. Como indica Nieto, este paradigma no tiene en cuenta que el silogismo no agota el razonamiento judicial, porque representa solo el iter que el juez sigue para alcanzar la decisión, pero no comprende la actividad esencial del juez. Seńala Nieto: "En el conflicto judicial no se trata de un negocio jurídico abstracto sino de una transferencia económica celebrada entre personas de carne y hueso en un día y en unas condiciones determinadas". En definitiva: "En cada decisión judicial individualizada se forma una cruz con un travesaño de singularidad y otro de subjetividad. La singularidad implica que cada decisión es única e irrepetible. Podrá haber casos similares e incluso idénticos, pero cada conflicto tiene solución propia, aunque coincida con la de los precedentes y predetermine los consiguientes" 33 .

Es el juez el que construye una norma para resolver el conflicto y, en ese entendido, la ley puede sufrir una transformación. No hay, desde la perspectiva de la argumentación jurídica, una respuesta judicial única. Como seńala Milagros Otero: "La afirmación de que el juez tiene que razonar aceptando la única respuesta correcta es siempre contrafáctica, de hecho no existe. Es más, en muchos casos las respuestas que se pueden obtener dependen de la argumentación utilizada y son tantas como argumentos válidos son empleados. Y por eso cualquier respuesta es válida siempre que no sea arbitraria" 34 .

31 Nos referimos al trabajo de los profesores Domínguez Hidalgo, Carmen y Domínguez Benavente, Ramón (1991), "Lo que la jurisprudencia se llevó". Revista de Derecho Universidad de Concepción, 189, pp. 96 y ss. Entre las materias en que la jurisprudencia ha alterado el criterio, destaca la indemnización de los perjuicios por dańo moral en sede contractual. Un proceso no menos interesante ha ocurrido en áreas bastante específicas de la responsabilidad extracontractual. En dicha sede, por ejemplo, los jueces, han buscado mecanismos para evitar la aplicación del artículo 2331, que parecería restringir la reparación del daño moral, en los casos de atentados injuriosos.

32 VIGo, Rodolfo (1992), "Paradigmas de la interpretación jurídico-judicial", en AA.VV. Interpretación, integración y razonamiento jurídicos, Santiago de Chile: Editorial Jurídica de Chile, p. 124.

33 Nieto, Alejandro (2000), El arbitrio judicial, Madrid: Ariel, pp. 127; 397.

34 Otero Parga, Milagros (2004), "La cuestión de la única respuesta judicial correcta", en AA.VV., La argumentación jurídica. Problemas de concepto, método y aplicación, Santiago de Compostela: Ediciones de la Universidad Santiago de Compostela, p. 323. Como indica Fueyo (1982) 3; 6, a propósito de la dificultad para encontrar la regulación de un régimen matrimonial idóneo, que respete los intereses de ambos contrayentes: "No sabemos, con todo, cómo hacerlo prácticamente, con normatividad idónea $y$, sobre todo, con soluciones a priori, ge- 
En suma, tratándose de la disolución de la sociedad conyugal en virtud del pacto de sustitución de régimen del artículo 1723, la discusión que se ha reseñado en los párrafos anteriores carece de interés práctico, aunque no teórico, porque se protegen expresamente los derechos de los terceros, adquiridos con anterioridad al pacto y, en consecuencia, a la liquidación. El efecto jurídico concreto que produce esta declaración legal, será una materia que analizaremos seguidamente.

Pero en los otros supuestos de disolución, la cuestión del efecto retroactivo de la adjudicación presenta indudablemente el problema de su extensión. Si bien es cierto la jurisprudencia ha limitado el efecto retroactivo de la adjudicación, no resulta claro su fundamento jurídico, porque no basta, a nuestro juicio, con declarar que debe limitarse al nacimiento de la comunidad. A diferencia de la comunidad hereditaria, la indivisión que deriva de la disolución de la sociedad conyugal no se genera como consecuencia de un modo de adquirir, como es la sucesión por causa de muerte. A nuestro juicio, dos puntos de vista pueden sostenerse: bien puede pensarse que el modo de adquirir que opera es la ley; bien, deberá reconocerse que los jueces han morigerado la norma, consagrando un principio general de protección de intereses de terceros.

\section{4) Problemas QUe Plantea El PaCTO DE SUSTITUCIÓN DE RÉGIMEN DEL ARTíCULO 1723 DEL Código CIVIL}

Detengámonos ahora en el pacto de sustitución de régimen, que es el que se encuentra más relacionado a las hipótesis en las que la jurisprudencia ha podido pronunciarse en relación con la disolución y liquidación de la sociedad conyugal. El pacto fue creado por la Ley 7.612, de 21 de octubre de 1943, pero su fisonomía actual fue introducida por la Ley 10.271, de 2 de abril de 1952, siendo el régimen matrimonial, hasta antes de su introducción, inmutable ${ }^{35}$. La Ley 19.335, de 23 de septiembre de 1994, finalmente, introdujo la posibilidad de sustituir el régimen de sociedad conyugal por el de participación en los gananciales, agregando

neralmente rígidas, obsesionados como estamos con la idea de encontrar absolutamente todo en la ley, desde el instante inicial de cada matrimonio, y olvidando el caleidoscopio infinito de casos que nos ofrece la realidad fenomenológica". Más adelante, agrega: “... ante la imposibilidad material de mirar con acierto hacia el futuro, siempre, en todo caso, se impone prever soluciones respecto de hechos pasados, por tanto, ciertos. ¿Cómo? Disponiéndose la solución judicial, en campos determinados, a petición de parte. El juez, obrando discrecionalmente, y atendiendo a pruebas que se rindan, en juicio, resolverá, lo que corresponda. No todo, repito, ha de estar necesariamente en la ley y de antemano".

35 Véase Domínguez Hidalgo, Ramón (1984), "El contrato en perjuicio de terceros". Revista de Derecho Universidad de Concepción, t. 175, p. 105. 
la posibilidad de sustituir el régimen de participación, por uno de separación o bienes o viceversa.

Las características del pacto han dado lugar a interesantes discusiones que, aunque no pueden ser analizadas en profundidad en este lugar, conviene al menos, dar una breve noticia de ellas. Una primera cuestión interesante es determinar su naturaleza jurídica, es decir, si estamos frente a una convención o, específicamente, ante un contrato. Peñailillo entiende que no parece propio calificarlo de un contrato, porque, en su opinión: "Del pacto no emergen, específicamente, obligaciones para los cónyuges, el efecto fundamental es reemplazar un régimen económico, en conjunto, por otro; el de sociedad conyugal o el de separación parcial, por el de separación total"36.

Nuestra doctrina, siguiendo la autoridad de Pothier y la escuela francesa, siempre ha distinguido entre convenciones y contratos, tomando en cuenta el contenido de ambos. La convención, como se sabe, es el acto jurídico bilateral cuyo objeto es la creación, modificación, transferencia o extinción de un derecho u obligación. El contrato, como categoría o especie de la convención, es el acto jurídico bilateral creador de derechos y obligaciones. Los autores chilenos coinciden, sin embargo, que esta distinción puede hacerse en ciencia pura, por cuanto esta no tiene importancia práctica, porque las reglas se aplican por igual al contrato obligacional como a los demás actos jurídicos bilaterales ${ }^{37,38}$.

36 Peñallillo, Daniel (1983), "El pacto de separación de bienes y el perjuicio a los acreedores". Revista de Derecho Universidad de Concepción, 173, p. 151. Cita Peñailillo un fallo de la Corte de Apelaciones de Santiago, publicado en RDJ, t. 56, sec. $1^{a}$, p. 347, que califica el pacto como contrato, aunque según el profesor, no era el asunto principal del juicio y la expresión pudo haberse debido más bien a una ligereza del lenguaje.

37 En este sentido, verbigracia, Corral Talciani, Hernán (2002), "La definición de contrato en el Código Civil Chileno y su recepción doctrinal. Comparación con el sistema francés", Documentos de Trabajo. Universidad de los Andes $\mathrm{N}^{\circ} 43$, p. 19. La obra también se encuentra publicada en Cuadernos de extensión jurídica. Derecho de los contratos, $\mathrm{N}^{\circ} 6$, cit., pp. 69 y ss. Alessandri Rodríguez, Arturo (1993), De los contratos, Santiago de Chile: Editorial Jurídica de Chile, p. 4.

38 Interesante resulta señalar que los primeros proyectos del Código Civil definían el contrato, siguiendo la tradición del Derecho natural racionalista y la del Código Civil francés, derechamente como una convención. Se piensa que la asimilación de los conceptos y la inclusión de una categoría más amplia -actos- (contrato o convención es un acto dice el artículo 1438 del actual texto) no se debe a un error del legislador, sino a la inclusión en nuestro sistema de la teoría alemana del negocio jurídico, introducida por Savigny. A este respecto, el profesor ConRaL (2002) 70, señala: “...Bello pretendió forjar una fórmula sincrética entre la doctrina del contrato que le era más familiar, (a través del Código Civil francés y sus principales comentaristas), y por la entonces novedosa teoría de la declaración de voluntad que planteaba Savigny en su Sistema de Derecho Romano Actual". Más delante, agrega: "El giro hacia la idea del negocio jurídico aparece en el llamado Proyecto Inédito (resultado de la revisión del texto de 1853), en el cual, a los preceptos ya afinados sobre la base de la figura del contrato, se superpone ahora una categoría más amplia: la del "acto voluntario", que sigue sin embargo dentro del Libro $I V$, el que continúa con el epigrafe "De las obligaciones en general y de los contratos". 
Sin embargo, en el tema que analizamos, la jurisprudencia ha encontrado un ámbito en el que la distinción ha recibido aplicación concreta. Dado que, como veremos, en el pacto es posible liquidar el régimen de sociedad conyugal, partiendo del supuesto que el acto mismo de liquidación es una convención y no un contrato, en la sentencia de la Corte Suprema, de 27 de julio de 2000, se negó la aplicación de la condición resolutoria tácita. Los contrayentes, habiéndose casado en el régimen de sociedad conyugal, decidieron pactar separación de bienes y liquidar la sociedad conyugal, por escritura pública de 22 de agosto de 1991. La demandante pretendía la resolución del pacto y de la liquidación, en atención a que se le había adjudicado un derecho inexistente sobre el Lote C, del Fundo El Molino, de la comuna de Machalí. La Corte rechazó esta pretensión, no solo porque la condición resolutoria táctica se aplica a los contratos y no a las convenciones, sino porque, rigiéndose la liquidación de la sociedad conyugal por las reglas de la partición, tampoco resulta aplicable a esta las reglas de la condición resolutoria tácita ${ }^{39}$.

En segundo lugar, estamos en presencia de un pacto solemne, porque debe celebrarse por escritura pública y subinscribirse al margen de la inscripción matrimonial, dentro del plazo de 30 días, contados desde el pacto. Como enfatiza Ramos, la subinscripción y el plazo para practicarla, tiene carácter de solemnidad y no solo de formalidad por vía de publicidad, porque, de no mediar dicha subinscripción, el pacto no tendrá efectos, ni entre las partes, ni respecto de terceros ${ }^{40}$.

En tercer lugar, el pacto es irrevocable. Ello quiere decir que, de acuerdo con el artículo 1716 del Código Civil, los cónyuges solo podrán, por una vez, pactar separación de bienes o participación en los gananciales para sustituir el régimen de sociedad conyugal. En otros términos, no es posible aceptar la resciliación del pacto. Para Ramos, sin embargo, con la Ley 19.335 subsiste un interesante problema. Si los cónyuges han pactado la sustitución de la sociedad conyugal, por separación de bienes, por ejemplo, ¿podrían pactar la sustitución del régimen de separación, por uno de participación en los gananciales o viceversa? Para Ramos, la expresión que emplea la ley no deja claro: “...si lo que se pretende es solo evitar la vuelta a la sociedad conyugal o su alcance es más general en el sentido que obsta también a que los cónyuges que se separaron de bienes puedan sustituir ese nuevo régimen por el de participación en los gananciales" ${ }^{41}$.

39 Sentencia publicada en Microjuris, MJJ3095 (fecha de la visita: 5 de enero de 2011). La doctrina está de acuerdo en que el acto de liquidación es una convención. Véase, por todos, Somarriva (2006) 279-280 y Peñailillo (1983) 153.

40 Ramos (2005) 240-241, quien señala que se trata de un plazo fatal y de días corridos, agregando la importante cuestión de que solo se aplica para la sustitución del régimen, no siendo necesario cumplir con dicho plazo, en el supuesto liquidación. Coincide, Troncoso (2006) 229.

41 Ramos (2006) 246; 294-295, quien parece aceptar la posibilidad, siguiendo a Merino Scheihing, Francisco (1996), "Consideraciones en torno al régimen de participación en 
En cuarto lugar, el pacto no puede estar sujeto a modalidades. Por la misma razón, podría pensarse, con buenos argumentos, que no es posible entender que en el pacto va envuelta la condición resolutoria tácita, como hemos analizado con anterioridad.

Finalmente, el pacto no puede afectar los derechos legítimos de terceros, lo que ha dado lugar a la mayor parte de los problemas relacionados con el pacto. Según el artículo 1723 el pacto no perjudicará, en caso alguno, los derechos válidamente adquiridos de los terceros. Como indica Peñailillo, el supuesto típico está representado por la celebración del pacto como mecanismo para eludir obligaciones (comúnmente dinerarias) contraídas por el marido antes de la celebración del pacto, liquidando en el acto la sociedad conyugal y adjudicándole los bienes a la mujer ${ }^{42}$.

De todos modos, no hay inconveniente alguno para que se produzca, hoy en día, la situación contraria, es decir, que la mujer pretenda eludir una deuda contraída con anterioridad a la celebración al pacto y que, en la liquidación de la sociedad conyugal, se adjudiquen todos los bienes al marido, recibiendo ella, en cambio, dinero. Pueden utilizarse, en este sentido, mecanismos adicionales para aparentar una genuina liquidación. Como por ejemplo, que el cónyuge que deba recibir su mitad de gananciales en dinero y no en los bienes (adjudicados al otro), lo reciba mediante letras de cambio giradas en su beneficio, aceptadas por el otro cónyuge, con ánimo de novar, lo que produce la extinción de las obligaciones que le dieron origen a la letra ${ }^{43}$.

Sin embargo, no ha sido feliz la inteligencia de la frase que consagró la protección de los terceros y, desde temprano, provocó problemas de interpretación. Para Somarriva, la frase empleada por el artículo 1723 no tiene sentido en la medida que la disolución de la sociedad conyugal tiene alcance limitado, quedando, en consecuencia, con pleno vigor los actos ejecutados vigente la sociedad conyugal. Tampoco tiene sentido la frase, en su concepto, tratándose de la acción pauliana, porque aunque el precepto no existiera, concurriendo mala fe, debería proceder esta. El objetivo de la disposición habría sido crear una "cua-

los gananciales en el Derecho Chileno", en AA.VV. Instituciones de Derecho Civil Moderno. Homenaje al profesor Fernando Fueyo Laneri, Santiago de Chile: Editorial Jurídica ConoSur, p. 193. En contra, Corral Talciani (2007), Bienes familiares y participación en los gananciales. La reforma de la Ley $N^{\circ} 19.335$, de 1994, a las relaciones personales y al régimen económico del matrimonio, Santiago de Chile: Editorial Jurídica de Chile, 2a edición actualizada, p. 186.

42 Peñailillo (1983) 146.

43 Como señalaba Domínguez (1984) 103: "Ha nacido, con tal motivo, una variedad de medios técnicos ideados para sustraer los bienes a la persecución de los acreedores. Nunca como ahora los cónyuges han visto que la sociedad de bienes es un régimen inadecuado y corren a separase de bienes...”. 
sipresunción" de fraude, considerando sospechosos los actos ejecutados en perjuicio de los acreedores y facilitando, de este modo, el ejercicio de la acción pauliana ${ }^{44}$.

Para Peńailillo, el pacto puede ser impugnado por cualquiera de estas tres vías: una acción pauliana, una acción ordinaria de inoponibilidad y una acción por simulación. A diferencia de Somarriva, la frase tiene sentido únicamente en el supuesto que pueda intentarse una acción de inoponibilidad, pues tanto en el supuesto de acción pauliana, como en el de simulación, bastaría remitirse a las normas generales ${ }^{45}$.

Tratándose de la acción pauliana, la principal dificultad en su aplicación estriba en la calificación que pudiese tener el pacto de sustitución y el acto posterior de liquidación. Según el autor, aunque el pacto de sustitución no pueda calificarse ni de oneroso (pues se trata de una convención destinada a regular las relaciones económicas entre los cónyuges, sin que importe necesariamente un gravamen en beneficio recíproco), es perfectamente aplicable la acción pauliana, por cuanto el artículo 2468, en su numeral segundo, se refiere en general a los actos y contratos no comprendidos en el número anterior, es decir, que no pueden ser calificados de onerosos. No existiría inconveniente en cuanto a la partición de común acuerdo, que se considera por la doctrina como una convención onerosa $^{46}$.

No parece haber, en cualquier caso, acuerdo en este punto en la doctrina. Para Abeliuk, por ejemplo, aun cuando la acción pauliana reconoce un campo amplio de acción, siempre que se trate de actos voluntarios del deudor, no estarían comprendidos los actos personalísimos, aunque tengan efectos patrimoniales. Cita al efecto el fallo de la Corte Suprema que desestimó el carácter de gratuito u oneroso, tanto del pacto como de la liquidación de la sociedad conyugal. El autor, desde luego, adhiere a la doctrina jurisprudencial citada por él ${ }^{47}$. Para Alessandri, Somarriva y Vodanovic parece todavía más dudosa su aplicación, porque, aun cuando no se pronuncian expresamente sobre el punto, exigen que el acto o convención sea de disposición, contrariamente a la doctrina sustentada por Abeliuk, notoriamente más amplia ${ }^{48}$.

44 Somarriva (1963) 307. Somarriva (2006) 526-528. Una opinión similar sostiene DomínGUEZ (1984) 107.

Peñailillo (1983) 149-150.

Peñailillo (1983) 150-153.

Abeliuk Manasevic, René (2001), Las Obligaciones, Santiago de Chile: Editorial Jurídica de Chile-Editorial Temis, 4a edición, pp. 696-697. Se trata de la sentencia publicada en RDJ, t. 67, sec. 1a, p. 463, también citada por Peńailillo (1983) 157.

48 Véase Alessandri R., Arturo, Somarriva U., Manuel y Vodanovic H., Antonio (2004), Tratado de las obligaciones, Santiago de Chile: Editorial Jurídica de Chile, $2^{\text {a }}$ edición ampliada y actualizada, t. II, pp. 210-211. 
En lo que toca a la acción de simulación, como indica Peñailillo: "Como todo acto que se celebra, conscientemente, sin la voluntad de realizarlo, el pacto de separación y la subsiguiente partición, si es el caso, son atacables por la vía de la simulación. Si ha habido simulación, lo más probable es que se trate de la denominada "absoluta" (tras el acto ostensible no se oculta ninguno). Solo se habría aparentado una separación y liquidación, pero se tiene la intención de continuar en el mismo estado de cosas (la continuación de la vida económica de los cónyuges, en la misma situación de antes, especialmente, la tendencia material de los bienes liquidados, sería uno de los elementos de prueba que tiende a configurarla)" 49 .

Como advierte el propio Peñailillo, se trata de una acción difícil de configurar. De hecho, hemos tomado conocimiento solo de muy pocos fallos que, conociendo la acción de simulación deducida en contra del pacto y la liquidación del régimen matrimonial, han tenido la oportunidad de pronunciarse sobre el punto.

La demandante había obtenido sentencia por despido injustificado, por la suma de \$9.350.000, confirmado la Corte de Apelaciones de Antofagasta, el 29 de abril de 2002 , de modo que se trataba de un crédito anterior a la liquidación de la sociedad conyugal. Para eludir dicha obligación, el empleador decidió pactar la sustitución del régimen y su cónyuge se adjudicó todos los bienes, evitando con ello el pago a la demandante.

La jueza de primera instancia, dońa Marcela Nilo Leyton, dio lugar a la demanda, declarando la simulación y, en consecuencia, la nulidad absoluta del pacto de separación y la liquidación de la sociedad conyugal, en la sentencia de 6 de agosto de 2007. Para la sentenciadora: "Que, de los hechos que han quedado establecidos en el motivo anterior, surgen una serie de presunciones suficientes, por su número, concordancia y armonía, para dar por acreditado en autos que la separación total de bienes y consiguiente liquidación de la sociedad conyugal que los cónyuges demandados, pactaron y ejecutaron el 31 de mayo de 2.002, fueron actos absolutamente simulados, los que configuran una pura apariencia sin contenido real y verdadero, toda vez que, en primer lugar, se llevaron a cabo justo cuando a la mujer se le habia condenado por sentencia que causaba ejecutoria, a pagar una indemnización ascendente a \$ 9.350.000.- a favor de una ex trabajadora, por haberla despedido en forma injustificada; y en segundo lugar, la forma en que se determinó el activo y pasivo de la sociedad conyugal y la tasación de los bienes; la renuncia a los gananciales de la mujer, quien tenía un patrimonio reservado ascendente a \$39.000.000.- versus el patrimonio social que alcazaba la suma de \$ 6.000.000.-; el traspaso de todos los bienes de ese patrimonio reservado al marido; el traspaso de la deuda hipotecaria al marido; la constitución de la Sociedad Educacional Limitada o Génesis Limitada en forma

49 Peñailillo (1983) 137. 
contemporánea; el traspaso de la calidad de sostenedora de la Escuela Especial de Lenguaje Nazareth de la Sra. Nury Acuña Ledezma a la sociedad mencionada; el hecho que tanto el inmueble adjudicado por el marido y los muebles que formaban parte del inventario de la escuela también adjudicados por el marido sigan siendo utilizados por la misma escuela; cuya Directora desde el año 2.002 ha sido la Sra. Nury Acuña, quien además figura desde un principio en el Banco del Estado como deudora del crédito hipotecario y quien paga los dividendos, el que fue adjudicado al marido, son todas circunstancias que indudablemente acreditan que en realidad los bienes reservados de la mujer nunca salieron de su patrimonio asi como tampoco la deuda hipotecaria que pagaba por el inmueble donde funciona la escuela de la cual era sostenedora y siempre ha sido su Directora, por lo tanto, constituye su empresa o negocio (considerando décimo quinto) ${ }^{\prime 50}$.

No obstante haberse acogido la demanda en primera instancia, la Corte de Apelaciones de Antofagasta, en la sentencia de 7 de marzo de 2008, la rechazó, entendiendo que las partes habrían querido, efectivamente, celebrar el acto y liquidar la sociedad conyugal. Ello, sin perjuicio de la inoponibilidad del pacto al acreedor. En el considerando primero, la Corte declaró, en el considerando primero: "Que de los hechos establecidos en el considerando $14^{\circ}$, no resultan elementos suficientes para declarar la nulidad del pacto de separación total de bienes y consiguiente liquidación de la sociedad conyugal. En efecto, el acto simulado es un acto ficticio, desprovisto de contenido, aún cuando sea lícito, realizado por las partes para engañar a terceros, pero no para que produzca efectos entre ellas, porque ésta fue su común intención al Otorgarlo. Ello no ocurre en el pacto de separación de bienes y la consiguiente liquidación de la sociedad conyugal cuya nulidad se solicita, los que son actos que si se miran en forma aislada, son inatacables porque no hay vicio alguno en ellos. Así, la terminación de la sociedad conyugal es real y definitiva, en los términos del artículo $1764 N^{\circ} 5$ del Código Civil y la sustitución de ese régimen por el de separación de bienes es efectiva

$50 \quad$ En el considerando vigésimo, se agrega: "Que, no está demás hacer presente que la acción de simulación que corresponde a los terceros, se parece en muchos casos a la acción pauliana o revocatoria, puesto que comúnmente la simulación es ilícita, es decir, el acto simulado tiene por finalidad cometer un fraude a la ley o perjudicar a los acreedores, la acción pauliana tiene por objeto dejar sin efecto los actos celebrados por el deudor en fraude de sus acreedores; sin embargo presentan diferencias bien precisas, tales como, la acción de simulación tiene por objeto demostrar que el acto no existe y la acción pauliana dejar sin efecto un acto perjudicial para los acreedores, pero que se ha celebrado efectiva y ostensiblemente; la acción de simulación pueden deducirla los acreedores, sin considerar la fecha de sus créditos, en cambio para deducir la acción pauliana es imprescindible haber tenido la calidad de acreedor antes de la celebración del acto que les perjudica; la acción de simulación corresponde a las partes y a los terceros, la acción pauliana solo compete a los acreedores en cuyo perjuicio se ha celebrado el acto; la acción revocatoria beneficia solo al acreedor que la entabla y la revocación no se extiende más allá del monto del crédito de ese acreedor, la simulación, en cambio, tiene un carácter absoluto y se demostrará que el acto no existe en su totalidad o que hay otro acto encubierto". 
de modo que, cualquiera sea la reacción que se produzca frente a terceros, ella produce todos los efectos legales entre los cónyuges. Por su parte, el traspaso de los bienes del marido a la mujer -aunque se haga con el solo efecto declarativo-es real y efectivo, y ha conducido a la adjudicación de los bienes a la mujer y al marido. No hay nada de oculto en ello. Eso es lo que se quiso y lo que se logró, aunque el propósito haya sido el burlar a terceros y escapar a las consecuencias del derecho de prenda general".

En cambio, el fallo de la Corte Suprema, de 19 de agosto de 2008, resolvió favorablemente la alegación de simulación acogiendo el recurso de casación intentado por el acreedor. En la sentencia de reemplazo, considerando séptimo: "Que los jueces para dar estricto cumplimiento a lo dispuesto anteriormente han debido emitir necesariamente pronunciamiento respecto de todos los presupuestos legales de la nulidad que se han invocado en este juicio. Empero, del fallo censurado se advierte que en las motivaciones allí contenidas no se analizó en ellas las alegaciones que la demandante efectuó en orden a advertir que en el caso de autos la voluntad declarada por los cónyuges es inexistente, esto atendido que si bien se realiza una afirmación sobre la ausencia de elementos suficientes para la declaración de nulidad del pacto de separación de bienes y liquidación de la sociedad conyugal, a continuación efectúa aseveraciones sobre la consecuencia de los actos que se impugnan, desatendiendo las argumentaciones de la parte demandante en orden a su carencia de causa. En efecto, nada se razona en el fallo sobre las consecuencias que ha de atribuirse a los innumerables hechos establecidos en la motivación décimo cuarta del fallo de primer grado, y que llevaron a concluir al sentenciador de primera instancia que los actos impugnados son aparentes y simulados y consecuentemente nulos por falta de consentimiento. Cuestión esta ultima que resulta indispensable para fundar la revocación del fallo que sustenta la sentencia impugnada. Cabe además destacar que si bien el fallo impugnado refiere en las motivaciones primera y segunda las razones para su decisión, de su análisis aparece que ambas argumentaciones resultan casi idénticas, siendo entonces la segunda de ellas una reiteración innecesaria que en nada aporta para la debida inteligencia del fallo y la compresión de lo resuelto, en orden al cumplimiento de las exigencias legales que se expusieron en la motivación anterior"s1.

Finalmente, Peñailillo justifica la frase consignada en el artículo 1723, en la medida que fundamentaría una acción ordinaria de inoponibilidad, como hemos visto. Pero el autor agrega la importante cuestión de que la expresión empleada en el artículo 1723 supone que el fraude que implica la acción de inoponibilidad no debe ser probado por el acreedor, a diferencia de la acción pauliana, en la que sí debería acreditarse dicho

51 Sentencia publicada en LegalPublishing $\mathrm{N}^{\circ} 42454$ (fecha de la visita: 20 de febrero de 2011). 
fraude. ${ }^{52}$ Con todo, la posición del citado autor parece discutible, desde que no existe diferencia, en lo que respecta a su naturaleza jurídica, entre la acción de inoponibilidad y la acción pauliana. De hecho, por ejemplo, Ducci, quien ha tratado expresamente la inoponibilidad por fraude, reconoce en el artículo 2468, precisamente, la consagración de la causal de ineficacia. De este modo, la opinión de Peñailillo, parece referir a la declaración del artículo 1723 simplemente un contenido del que carece ${ }^{53}$.

Hay otras alternativas planteadas por Peñailillo, como la ejecución de la mujer, amparados en la aceptación de los gananciales y en su obligación de contribuir al pago de las deudas sociales, fundado especialmente en el artículo 1777. También indica que se ha discutido la posibilidad de demandar ejecutivamente al marido y, en dicho juicio, embargar los bienes adjudicados a la mujer. Ramos Pazos indica que todas estas alternativas son propuestas por Peńailillo como diferentes posibilidades de actuación del acreedor, pero lo cierto es que Peñailillo se opone, al menos, a esta última alternativa, pues considera que supone otorgarle una interpretación excesiva al artículo 1723. Advierte que una vez subinscrito, el pacto tiene efectos absolutos, que no podrían operar respecto del acreedor. En consecuencia, estima que el acreedor debería probar, al menos, el perjuicio irrogado por el pacto y la subsecuente liquidación ${ }^{54}$.

La observación de Peńailillo es acertada, en el sentido de que permitir el embargo de los bienes de la mujer, cuando se le han adjudicado los bienes, como si el pacto no existiese, supone entender la inoponibilidad como una sanción que opera de pleno derecho. Sin embargo, es necesario hacer notar que se trata de una opinión aceptada en algún sector de la doctrina. Claro Solar, en efecto, parece inclinarse en este sentido: "Si los cónyuges se hallaban casados bajo el régimen de sociedad conyugal y pactan separación total de bienes, los bienes que correspondan a la mujer y que formaban parte del haber social podrán ser perseguidos por los acreedores como si la separación de bienes no se hubiere pactado; y la mujer no podrá oponerles el nuevo pacto e invocar el nuevo régimen de bienes en él pactado para liberarse de la responsabilidad que afectaba a estos bienes, ni para desconocer los derechos reales que sobre ellos se hubieren constituido por el marido a favor de terceros" 55 .

¿Qué ocurre con la jurisprudencia?, ¿cuál es el alcance la fórmula de no perjuicio a los terceros? En esta materia, los tribunales han asumido, a nuestro juicio, dos posiciones claramente diferenciadas y que se han

Peñailillo (1983) 159.

Véase Ducci Claro, Carlos (2002), Derecho Civil, Parte General, Santiago de Chile: Editorial Jurídica de Chile, 4a edición actualizada, pp. 353-354.

54 Véase Ramos Pazos (2005) 244 y Peñailillo (1983) 163-164.

55 Claro Solar, Luis (1977), Explicaciones de Derecho Civil chileno y comparado, Santiago de Chile: Universitarias, t. II, p. 273. 
analizado en los párrafos precedentes. Un grupo de sentencias, de las que tomaremos algunos ejemplos, estima que estamos frente a una inoponibilidad de pleno derecho, porque permiten al acreedor, especialmente en el contexto de un juicio ejecutivo, dirigirse en contra del cónyuge deudor y los bienes adjudicados al otro, como si el pacto no hubiese existido. De otro lado, otro grupo exige que se deduzca, necesariamente, una acción de inoponibilidad, sosteniendo que, en dicho supuesto, el acreedor debe acreditar el perjuicio.

El primer grupo de sentencias, como hemos dicho, parecen entender que estamos frente a una inoponibilidad de pleno derecho. En este sentido resolvió la sentencia de la Corte de Apelaciones de Concepción, de 6 de septiembre de 1994. Los hechos que motivaron el proceso son, en breve síntesis, los siguientes: el 23 de mayo de 1992, se condena a Jorge González como autor del delito de homicidio simple en la persona de Miguel Bascur, condenando al pago de $\$ 3.240 .000$, a título de daños. A la fecha del daño (1990), el autor se encontraba casado en sociedad conyugal con Magdalena Pérez Muñoz. El 6 de marzo de 1992, celebran el pacto de sustitución de régimen, pactando separación de bienes y liquidando la sociedad conyugal, adjudicando los bienes a la mujer.

Ejercida la acción civil por la madre del fallecido, la responsabilidad civil del marido, pero se persiguieron los bienes adjudicados a la mujer. La Corte entendió que la celebración del pacto era un derecho absoluto, pero: "no puede perjudicar en modo alguno los derechos válidamente adquiridos por terceros respecto del marido o de la mujer" (considerando quinto). En consecuencia, resolvió que la madre del fallecido tenía derecho a perseguir los bienes, al tiempo del delito, sociales, como si el pacto no se hubiere celebrado (considerando quinto), debiendo rechazarse la tercería de posesión (considerando sexto) ${ }^{56}$.

En la sentencia de la Corte Suprema, de 23 de enero de 1990, en el juicio ejecutivo deducido por Banco Estado contra Enrique Luchsinger, rol $\mathrm{N}^{\circ}$ 13.259, se suscitaron los siguientes hechos: Banco Estado impetró y obtuvo embargo sobre el bien raíz que, al tiempo de contraerse el crédito, era social. La mujer dedujo, esta vez, tercería de dominio respecto del bien embargado, por cuanto había sido adjudicado en razón del pacto del artículo 1723. Dicha tercería, había sido rechazada tanto en primera como en segunda instancia. La Corte Suprema entendió que el artículo 1723 no podía perjudicar a los acreedores del marido, pues no se practicó, con las solemnidades exigidas, el inventario y tasación contemplado en los artículos 1765 y $1766^{57}$.

56 Sentencia publicada en Microjuris. Indicador MJJ2929 (fecha de la consulta: 5 de enero de 2011).

57 Sentencia publicada e LegalPublishing. Indicador $N^{\circ} 10903$ (fecha de la consulta: 5 de enero de 2011). La Corte Suprema ha mantenido a lo largo del tiempo este criterio, como 
Como se aprecia en las sentencias comentadas, con independencia de la fuente de la obligación, es decir, se trate de un delito o cuasidelito o bien de una fuente convencional, los tribunales han interpretado mayoritariamente que el cónyuge puede oponerse al embargo del bien adjudicado, sin necesidad que el acreedor rinda prueba alguna. Este criterio debe ser complementado con la tendencia jurisprudencial tendiente a restringir o limitar los alcances retroactivos de la adjudicación, materia a la que nos hemos referido detalladamente. No obstante, hay que reconocer la interesante cuestión de que la Corte rechaza la tercería porque el embargo era anterior al acto de adjudicación. Es interesante preguntarse, por el contrario, por el criterio jurisprudencial que debe seguirse, en los casos en que bienes inmuebles sean adjudicados y se intente un embargo con posterioridad a dicho acto, fundándose en una deuda anterior al pacto.

Una tendencia minoritaria entiende que la inoponibilidad debe ser declarada, exigiendo el perjuicio del acreedor. En este sentido se pronunció el fallo de la Corte Suprema de 30 de agosto de 2004. En el caso fallado por la Corte, Sergio Faúndez, conduciendo el 25 de febrero de 1997, el bus Mercedes Benz, de propiedad de Alfonso Martínez Catalán, a exceso de velocidad, provocó la muerte de Sok Kyu Pak, quien salió expedido del mismo. El 21 de marzo de 1997, Alfonso Martínez celebra con su cónyuge separación de bienes, adjudicándose solo el referido bus. Los herederos deducen demanda de indemnización y de inoponibilidad del pacto de separación, el 20 de mayo de 1997.

Para la Corte, siguiendo criterio ya examinado precedentemente, la deudas derivadas de la responsabilidad extracontractual, son deudas sociales, considerando, por consiguiente, que incurría en error de Derecho la sentencia de $2^{\circ}$ grado que había establecido lo contrario (considerando

se desprende, por ejemplo, de sentencias mucho más recientes. En el fallo de 9 de abril de 2002, en la causa rol N ${ }^{\circ}$ 679-2001, caratulada Cruz Ramírez, Gladis con Lira Infante, Manuel, $\mathrm{N}^{\circ}$ de indicador LegalPublishing 24219 (fecha de la consulta: 5 de enero de 2011), la Corte declaró que: "No puede prosperar la tercería de posesión sobre un inmueble, basándose para ello en una escritura de separación de bienes que adjudicó el inmueble a la tercerista, si dicha adjudicación se inscribió a su nombre en el respectivo Conservador de Bienes Raices solo con posterioridad a la existencia del embargo, de tal manera que al momento del apremio figuraba inscrita a nombre del ejecutado. En ese contexto, cobra relevancia lo dispuesto en el artículo 1723 inciso segundo del Código Civil, conforme al cual el pacto de separación de bienes no perjudicará, en caso alguno, los derechos adquiridos válidamente por terceros respecto del marido". En la sentencia de 21 de julio de 2010, en la causa rol No 7976-2010, caratulada Compañía de Telecomunicaciones con Edmundo Vergara Astorga, publicada en LegalPublishing, indicador $\mathrm{N}^{\circ} 44936$ (fecha de la visita: 5 de enero de 2011). La Corte declaró que el derecho de prenda general del acreedor y ejecutante sobre los bienes del ejecutado al tiempo de contraerse la deuda, se vio menoscabado por el pacto de separación del bienes: "...Por tanto, se ha configurado en el presente caso, la hipótesis del artículo 1723 inciso $2^{\circ}$ del Código Civil, esta es, que el pacto de separación total de bienes produzca perjuicio en los derechos válidamente adquiridos por terceros", razonamiento que condujo a la Corte a desestimar la tercería de posesión deducida por el adjudicatario. 
décimo). Agregó la Corte que no debía probarse, en la acción de inoponibilidad, el fraude de acreedores, sino que bastaba la existencia del perjuicio, consistente en la dificultad de obtener el pago del crédito (considerando décimo primero).

\section{CONCLUSIONES}

Como hemos podido apreciar, al margen de que el régimen de sociedad conyugal requiera una urgente revisión no ha habido una reflexión profunda sobre los complejos problemas que proponen tanto la disolución, como la liquidación del régimen.

Es relativamente simple encontrarse con opiniones que sostiene que en determinados ámbitos del Derecho ya se ha dicho o planteado todo, y que, en consecuencia, determinados conceptos, no merecerían una revisión que fuese digna de una trabajo de investigación. Y, si se trata de la sociedad conyugal, esta afirmación es, a menudo, categórica. Ello es porque el instituto se ha rodeado de paradigmas (en el sentido científico de la expresión y no en su uso corriente). No es que las cuestiones relativas a la sociedad conyugal estén rodeadas de ejemplos o modelos, sino de ciertos conceptos o reglas que rigen la disciplina, que se han ido asentando en la dogmática, al punto que tales afirmaciones revelarían, por sí mismas, la verdadera naturaleza de lo que la sociedad conyugal es.

Pensar de este modo sería una falacia, pues los problemas sobre las materias propuestas en este artículo, dan cuenta de una discusión inacabada. Hay buenas razones para dudar del carácter de universalidad jurídica de la comunidad, disuelta la sociedad conyugal, hay cuestiones que requieren una discusión más detenida, en el caso de la regla general asumida por la jurisprudencia, en el sentido de limitar el efecto retroactivo de la adjudicación consagrada en el artículo 1344. Finalmente, el pacto de sustitución de régimen es el que ha posibilitado el pronunciamiento de la mayor parte de la jurisprudencia, en la medida que se ha empleado como mecanismo para eludir las obligaciones contraídas con anterioridad a la celebración del pacto. De todos estos extremos hemos dado cuenta en este trabajo, proponiendo, en cada caso, nuestra propia visión.

\section{BIBLIOGRAFÍA}

Abeliuk Manasevic, René (2001), Las Obligaciones, Santiago de Chile: Editorial Jurídica de Chile-Editorial Temis, 4a edición.

Aedo Barrena, Cristián y Mondaca Miranda, Alexis (2009), "Regulación jurídica de las parejas de hecho: sobre por qué no equipararlas al matrimonio. Una reflexión desde el caso español”. 
Carlos Pizarro Wilson (coordinador), Estudios de Derecho Civil IV, Jornadas Nacionales de Derecho Civil Olmué, 2008, Santiago de Chile: LegalPublishing.

Alessandri Rodríguez, Arturo (1993), De los contratos, Santiago de Chile: Editorial Jurídica de Chile.

Alessandri R., Arturo / Somarriva U., Manuel / Vodanovic H., Antonio (2001), Tratado de los Derechos reales, Santiago de Chile: Editorial Jurídica de Chile, 6a edición, t. I.

Alessandri R., Arturo / Somarriva U., Manuel / Vodanovic H., Antonio (2004), Tratado de las obligaciones, Santiago de Chile: Editorial Jurídica de Chile, 2a edición ampliada y actualizada, t. II.

Barros Errázuriz, Alfredo (1931), Curso de Derecho Civil, Santiago de Chile: Editorial Nascimento, vol. IV.

Belluscio, Augusto César (2004), Manual de Derecho de Familia, Buenos Aires: Astrea, $1^{\text {a }}$ reimpresión de la $7^{\text {a }}$ edición, t. II.

Bossert, Gustavo y Zannoni, Eduardo (2004), Manual de Derecho de Familia, Buenos Aires: Astrea, 6a edición actualizada.

Claro Solar, Luis (1977), Explicaciones de Derecho Civil chileno y comparado, Santiago de Chile: Universitarias, t. II.

Corral Talciani, Hernán (2002), "La definición de contrato en el Código Civil Chileno y su recepción doctrinal. Comparación con el sistema francés", Documentos de Trabajo. Universidad de los Andes $\mathrm{N}^{\circ} 43$.

(2007), Bienes familiares y participación en los gananciales. La reforma de la Ley $N^{\circ}$ 19.335, de 1994, a las relaciones personales y al régimen económico del matrimonio, Santiago de Chile: Editorial Jurídica de Chile, $2^{\text {a }}$ edición actualizada.

(2007), "Reforma al régimen de bienes del matrimonio. Reflexiones críticas sobre el Proyecto de Ley que sustituye la sociedad conyugal como régimen legal supletorio". Documento de trabajo. Universidad de los Andes, 66.

Court Murasso, Eduardo (2009), Curso de Derecho de Familia, Santiago de Chile: LegalPublishing.

Díez-Picazo, Luis y Gullón, Antonio (2003), Sistema de Derecho Civil, Madrid: Tecnos, $11^{\text {a }}$ edición, vol. I.

Domínguez Hidalgo, Ramón (1984), "El contrato en perjuicio de terceros". Revista de Derecho Universidad de Concepción, t. 175, p. 105.

Domínguez Hidalgo, Carmen / Domínguez Benavente, Ramón (1991), "Lo que la jurisprudencia se llevó". Revista de Derecho Universidad de Concepción, 189.

Ducci Claro, Carlos (2002), Derecho Civil, Parte General, Santiago de Chile: Editorial Jurídica de Chile, $4^{a}$ edición actualizada.

Frigerio Castaldi, César (1995), Regimenes matrimoniales, Santiago de Chile: Editorial Jurídica ConoSur. 
Fueyo Laneri, Fernando (1959) Derecho Civil, t. VI: Derecho de Familia, Santiago de Chile: Imprenta Universo.

(1985), "Problemática general del régimen patrimonial del matrimonio". Revista de Derecho y Jurisprudencia, t. 82.

Gazmuri Riveros, Consuelo (1996), "Uniones de hecho: algunos antecedentes, y problemáticas de la regulación jurídica de sus efectos". A.A.V.V. Instituciones Modernas de Derecho Civil. Homenaje al profesor Fernando Fueyo Laneri, Santiago de Chile: ConoSur, 1996.

Laurent, F. (1878), Principes de Droit Civil, Bruselas: Bruylant, $3^{\mathrm{a}}$ edición, t. 21.

Lira Urquieta, Pedro (1936), "Algunas consideraciones sobre el estado de indivisión que sigue a la disolución de la sociedad conyugal". Revista de Derecho y Jurisprudencia, t. 33.

López Díaz, Carlos (2005), Manual de Derecho de Familia y Tribunales de Familia, Santiago de Chile: Librotecnia, 2a edición, t. I.

Merino Scheihing, Francisco (1996), "Consideraciones en torno al régimen de participación en los gananciales en el Derecho Chileno", en AA.VV. Instituciones de Derecho Civil Moderno. Homenaje al profesor Fernando Fueyo Laneri, Santiago de Chile: Editorial Jurídica ConoSur.

Nieto, Alejandro (2000), El arbitrio judicial, Madrid: Ariel.

Otero Parga, Milagros (2004), "La cuestión de la única respuesta judicial correcta”, en AA.VV., La argumentación jurídica. Problemas de concepto, método y aplicación, Santiago de Compostela: Ediciones de la Universidad Santiago de Compostela.

Peñailillo, Daniel (1983), "El pacto de separación de bienes y el perjuicio a los acreedores". Revista de Derecho Universidad de Concepción, 173.

Peñailillo Arévalo, Daniel (2002), Los bienes. La propiedad y otros derechos reales, Santiago de Chile: Editorial Jurídica de Chile, $3^{a}$ edición.

Ramos Pazos, René (2005), Derecho de Familia, Santiago de Chile: Editorial Jurídica de Chile, 5a edición actualizada.

Rodríguez Grez, Pablo (1996), Regimenes Patrimoniales, Santiago de Chile: Editorial Jurídica de Chile.

Rozas Vial, Fernando (1989), "Consideraciones sobre las modificaciones que la Ley N ${ }^{\circ} 18.802$ introduce al Código Civil”. Revista Chilena de Derecho, vol. 16, 1.

Silva Segura, Enrique (1985), Acciones, actos y contratos sobre cuotas, Santiago de Chile: Editorial Jurídica de Chile.

Somarriva Undurraga, Manuel (1963), Derecho de Familia, Santiago de Chile: Editorial Nascimento. 
(2005), Derecho Sucesorio Santiago de Chile: Editorial Jurídica de Chile, $7^{a}$ edición actualizada, versión de René Abeliuk, t. II.

(2006), Indivisión y partición, Santiago de Chile: Editorial Jurídica de Chile, reimpresión de la $5^{\text {a }}$ edición, actualizada por Gonzalo Figueroa Yáñez.

Stitchkin B., David (1949), "Comentario a la sentencia de la Corte Suprema, de 18 de marzo de 1948". Revista de Derecho y Jurisprudencia, t. 46, $2^{\text {a }}$ parte, sec. $2^{\text {a }}$

Troncoso Larronde, Hernán (2006), Derecho de Familia, Santiago de Chile: LexisNexis, $8^{a}$ edición.

Turner Saelzer, Susan (2008), "Uniones de hecho y regulación legal". A.A.V.V. Estudios de Derecho Civil III. Jornadas Nacionales de Derecho Civil, Santiago de Chile: LexisNexis.

Viera Álvarez, Christian (2008), "El concepto de familia y la unión civil de personas del mismo sexo. Comentario de jurisprudencia a la aplicación de la ley de violencia intrafamiliar". Nomos. Revista de la Facultad de Derecho, Universidad Viña del Mar. No 1.

VIGo, Rodolfo (1992), "Paradigmas de la interpretación jurídicojudicial”, en AA.VV. Interpretación, integración y razonamiento jurídicos, Santiago de Chile: Editorial Jurídica de Chile.

Vodanovich H., Antonio (2001), Manual de Derecho Civil. Parte preliminar y general, Santiago de Chile: ConoSur. 